\title{
SYMBOLS OR SUBSTANCE? \\ Priorities for the Reform of Australian Public Interest Disclosure Legislation
}

\author{
AJ Brown and Paul Latimer*
}

The last 15 years have seen many developments in Australian public interest disclosure or 'whistleblower protection' legislation. Since 1993, every Australian public law jurisdiction has enacted or introduced such legislation, and in 2004 comparable provisions were extended into Australian corporate law, and to a lesser extent workplace relations (2007). Further, the new Commonwealth Labor government has committed to introduce new 'best practice' public interest disclosure legislation for federal officials. This article presents key results from a comparative analysis of existing legislative regimes, focusing on five issues: who may disclose wrongdoing in the public interest; the types of wrongdoing that may be disclosed; the protection of 'public' as opposed to internal or regulatory whistleblowing; compensation mechanisms for aggrieved whistleblowers; and how best to codify the obligations of all employers - public or private - towards employees who blow the whistle in the public interest. This analysis demonstrates the need for greater consistency in the key legal thresholds and requirements imposed by Australian whistleblower protection regimes, and the potential for common approaches covering both the public and private sectors. In large part, the prospect for a faster transition to more effective, less 'symbolic' regimes depends on a clearer consensus about the public importance of employee disclosures and the organisational advantages of open, proactive approaches to disclosure management.

\section{Introduction}

Since the 1970s, the willingness of public officials to voice concerns on matters of public interest has been recognised as fundamental to democratic accountability and public integrity. In parallel, the willingness of private sector employees to do the same has been recognised as fundamental to good corporate

AJ Brown is Senior Research Fellow, Griffith Law School, Griffith University. Paul Latimer is Associate Professor, Department of Business Law and Taxation, Monash University. This research was made possible by funding from the Australian Research Council (ARC Linkage Project LP0560303) and the various industry partners to this project, as listed on the project website www.griffith.edu.au/whistleblowing. The authors thank their colleagues on the Whistling While They Work Project Team as well as these industry partners and the participants for their assistance with this research. The findings and views expressed in this paper are those of the authors and do not necessarily represent the views of the Australian Research Council or the project industry partners. 
governance, consumer protection, the interests of shareholders and corporate social responsibility. At the same time, however, 'whistleblowing' is one of the most complex, conflict-ridden areas of public policy and legislative practice. This can be seen clearly in Australia, where in the last 15 years, all nine public law jurisdictions have either passed or, in the case of the Northern Territory, introduced special purpose public interest disclosure legislation, and equivalent provisions have begun to appear in laws pertaining to governance in the private sector.

This article presents key results from a comparative analysis of Australia's 11 public sector laws and Bills in this field to late 2006 (Table 1), along with some broader comparison with current trends in the private sector. It forms part of a larger research project, 'Whistling While They Work: Enhancing the Theory and Practice of Internal Witness Management in Public Sector Organisations', studying the reality as well as the rhetoric of Australian schemes for the management of whistleblowing.

Table 1: Australian public interest disclosure Acts \& Bills (public sector), in date order

\begin{tabular}{|c|c|c|}
\hline No. & Act / Bill & Jurisdiction \\
\hline 1 & Whistleblowers Protection Act 1993 & South Australia \\
\hline 2 & Whistleblowers Protection Act 1994 & Queensland \\
\hline 3 & Protected Disclosures Act 1994 & New South Wales \\
\hline 4 & Public Interest Disclosure Act 1994 & $\operatorname{ACT}(1)$ \\
\hline 5 & $\begin{array}{l}\text { Public Service Act 1999, s } 16 \text { 'Protection for } \\
\text { whistleblowers' }\end{array}$ & Commonwealth (1) \\
\hline 6 & $\begin{array}{l}\text { Public Interest Disclosure (Protection of } \\
\text { Whistleblowers) Bill } 2002\end{array}$ & Commonwealth \\
\hline 7 & Whistleblowers Protection Act 2001 & Victoria \\
\hline 8 & Public Interest Disclosures Act 2002 & Tasmania \\
\hline 9 & Public Interest Disclosure Act 2003 & Western Australia \\
\hline 10 & $\begin{array}{l}\text { Public Interest Disclosure Bill } 2006 \\
\text { (Government Bill) }\end{array}$ & Northern Territory \\
\hline 11 & $\begin{array}{l}\text { Public Interest Disclosures Bill } 2006 \\
\text { (Government Bill) }\end{array}$ & $\mathrm{ACT}(2)$ \\
\hline 12 & Public Interest Disclosures Bill 2007 & Commonwealth (3) \\
\hline
\end{tabular}

Much of the empirical research associated with this study is reported elsewhere, including with respect to its specific implications for legislation. ${ }^{1}$ However, many of the major issues confronting the future of public interest disclosure legislation are also demonstrated by comparing and contrasting the existing public sector laws, using 10 fundamental questions:

1 How should whistleblowing be defined (and what should be the title and objectives of the legislation)?

2 Who should be eligible for whistleblower protection?

Brown (2008). 
3 Should public and private sector whistleblowing be in the same law?

$4 \quad$ What types of wrongdoing should be able to be disclosed?

5 How do we guard against misuse of whistleblowing processes?

6 How should disclosures be received, handled and investigated?

7 How can legal protection of whistleblowers be made more effective?

8 The public interest 'leak': when should disclosures to non-government actors be protected?

9 How should whistleblowers and internal witnesses be managed?

10 How can public integrity agencies play more effective roles in the management of whistleblowers and internal witnesses?

These questions are set out more fully in an Issues Paper published by three of the partner organisations to this project, ${ }^{2}$ and provoke a large number of issues should any Australian jurisdiction wish to pursue legislative best practice, even within the public law realm. Currently, no existing Australian whistleblowing law or Bill supplies a single 'best practice' model, with every jurisdiction having managed to enact at least some elements of best practice, but with every instrument also experiencing problems - sometimes unique, sometimes general or sometimes common. For this reason alone, a more considered debate is needed on the strengths and weaknesses of the legislation, so that all jurisdictions might progress towards a better framework. The most effective path to better legislative practice now appears to involve a new 'second generation' of more consistent whistleblower laws, drawing on all the lessons of the first generation.

Fortunately, the scope for such an overhaul has widened in recent years and months. Formal legislative reviews are underway in a number of state jurisdictions. In May 2007, subsequent to the publication of the Issues Paper just mentioned, a further Commonwealth Private Member's Bill was introduced by Senator Andrew Murray, demonstrating that with relative simplicity a far more comprehensive and effective legislative approach is possible. ${ }^{3}$ Most importantly, the election of the Rudd Labor Commonwealth government in November 2007 brought with it an express commitment to the introduction of 'best-practice legislation to encourage and protect public interest disclosure within government'. ${ }^{4}$

This article underscores the argument for comprehensive reform of this kind, and seeks to help inform it, by reviewing five significant issues arising from the questions above. The first and second parts of the article discuss two issues that clearly demonstrate the need for consistency in the basic presumptions and mechanisms of such legislation: first, who may be regarded, and protected, as a 'whistleblower'; and second, what types of wrongdoing may form the subject of disclosures which then trigger the processes under the legislation. The first question reveals major confusion because, while some laws are only triggered by disclosures made by whistleblowers, many are triggered

Brown (2006).

Public Interest Disclosures Bill 2007 (Cth).

Rudd and Ludwig (2007), p 8. 
by complaints made by any person, fostering the problematic notion that in fact anyone in any circumstances can be a whistleblower. The second question reveals that currently in some states a wide range of individual or organisational wrongdoing may be disclosed, while in others it is only very narrow categories of criminal or serious disciplinary misconduct.

The third and fourth parts of the article focus less on inconsistencies than on gaps - in particular, the lack of legal protection flowing to whistleblowers who, in justifiable circumstances, make their disclosure public by going to the media or other third parties; and the lack of effective compensation mechanisms for aggrieved whistleblowers, without which protection is at best nominal. In each case, only one existing Australian law points the way towards an effective mechanism, with the equivalent UK legislation also providing a useful counterpoint on issues which are fundamental to the credibility of an effective public interest disclosure regime.

The fifth and final part of the article deals with the question of whether the search for greater consistency and more effective uniformity is now best pursued through a combination of public sector laws, private sector laws, and sector-blind employment-based laws. An analysis of the current state of private sector and public sector provisions suggests that, while Australia has now moved beyond the point where a single 'sector-blind' public interest disclosure regime is either possible or desirable, there is need and potential to strengthen the protection of whistleblowers through measures that recognise the protection obligations that fall on all employers, irrespective of whether they lie in the public or private sectors. The decision of the High Court in WorkChoices $(2006)^{5}$ also increases this potential, given that it increases the extent to which a uniform national approach to these obligations could now be enforced across a wider range of employers.

The conclusion reached through this analysis is not only that reform of existing whistleblowing legislation is needed, but that with sufficient care and attention it is also possible. Notwithstanding new interest in reform at the Commonwealth level, the deficiencies in existing legislative approaches are such that critics have long feared that public sector whistleblower protection is something of a chimera. Indeed, there is a valid question as to whether 'whistleblower protection' laws have not functioned as simply symbolic measures. While no doubt introduced with good intentions, there is a fear that such legislation may actually have served to increase the risk of reprisals against employees, lulling them into the false confidence that they will be protected if they blow the whistle, when in truth the legislative systems provide few guarantees that this will be the case. ${ }^{6}$ In those jurisdictions where the law carries public reporting obligations, ${ }^{7}$ we know that many hundreds of public employees

$5 \quad$ New South Wales \& Ors v Commonwealth of Australia [2006] HCA 52; (2006) 81 ALJR 34; Bennett v President, Human Rights and Equal Opportunity Commission [2003] FCA 1433 per Finn J.

6 De Maria (1999)

7 Brown (2006), pp 32-33. 
do make disclosures each year, which are treated seriously and substantiated at a rate exceeding that of misconduct allegations received from other sources. ${ }^{8}$

Nevertheless results from the empirical research of the 'Whistling While They Work' project confirm that while most (61 per cent) of those employees who are aware of the legislation agree that it makes it easier for them to consider reporting wrongdoing, and half $(50 \%)$ are also confident that their organisation seeks to follow the 'principles' of whistleblower protection, only $38 \%$ are confident that the legislation would actually protect them from negative consequences, or that the legislation is actually effective (see Table 2). In other words, the symbolic purposes and values of the legislation are clear. Indeed, the empirical research establishes that in public sector agencies where staff have an increased awareness of and confidence in the legislation, there is also increased trust in the likely management response, should they blow the whistle - even though there is little evidence that the response will, in fact, be any different. ${ }^{9}$

Table 2: Confidence in Australian public interest disclosure legislation ${ }^{10}$

\begin{tabular}{|l|l|l|l|l|l|l|}
\hline & $\begin{array}{l}\text { Strongly } \\
\text { disagree }\end{array}$ & Disagree & $\begin{array}{l}\text { Neither } \\
\text { disagree } \\
\text { nor agree }\end{array}$ & Agree & $\begin{array}{l}\text { Strongly } \\
\text { agree }\end{array}$ & Total \\
\hline $\begin{array}{l}\text { The existence of the } \\
\text { legislation makes it } \\
\text { easier for me to } \\
\text { consider reporting } \\
\text { corruption. }\end{array}$ & $\begin{array}{l}2 \% \\
(72)\end{array}$ & $\begin{array}{l}8 \% \\
(323)\end{array}$ & $\begin{array}{l}29 \% \\
(1127)\end{array}$ & $\begin{array}{l}50 \% \\
(1953)\end{array}$ & $\begin{array}{l}11 \% \\
(435)\end{array}$ & $\begin{array}{l}100 \% \\
(3910)\end{array}$ \\
\hline $\begin{array}{l}\text { The principles of the } \\
\text { legislation are } \\
\text { followed in this } \\
\text { organisation. }\end{array}$ & $\begin{array}{l}2 \% \\
(79)\end{array}$ & $\begin{array}{l}(2 \% \\
\text { (242) }\end{array}$ & $\begin{array}{l}41 \% \\
(1602)\end{array}$ & $\begin{array}{l}44 \% \\
(1714)\end{array}$ & $\begin{array}{l}6 \% \\
(245)\end{array}$ & $\begin{array}{l}100 \% \\
(3882)\end{array}$ \\
\hline $\begin{array}{l}\text { legislation has the } \\
\text { power to protect me } \\
\text { from any negative } \\
\text { consequences if I } \\
\text { were to report } \\
\text { corruption. }\end{array}$ & $\begin{array}{l}7 \% \\
(255)\end{array}$ & $\begin{array}{l}22 \% \\
(844)\end{array}$ & $\begin{array}{l}38 \% \\
(1470)\end{array}$ & $\begin{array}{l}29 \% \\
(1135)\end{array}$ & $\begin{array}{l}5 \% \\
(200)\end{array}$ & $\begin{array}{l}100 \% \\
(3904)\end{array}$ \\
\hline $\begin{array}{l}\text { I believe the legis- } \\
\text { lation is ineffective. }\end{array}$ & $\begin{array}{l}4 \% \\
(172)\end{array}$ & $\begin{array}{l}30 \% \\
(1169)\end{array}$ & $\begin{array}{l}52 \% \\
(1996)\end{array}$ & $\begin{array}{l}11 \% \\
(428)\end{array}$ & $\begin{array}{l}3 \% \\
(111)\end{array}$ & $\begin{array}{l}100 \% \\
(3876)\end{array}$ \\
\hline
\end{tabular}

Brown et al (2006).

9 Roberts in Brown (2008).

10 Responses to questions 16 and 17 of the 2006 WWTW Workplace Experience and Relationships Questionnaire, administered to approximately 23000 public employees in 118 agencies of the Commonwealth, NSW, Queensland and WA public sectors in July-September 2006. Total responses $=7663$, of whom 42 per cent $(n=3,187)$ indicated a belief that they were covered by public interest disclosure legislation. 
These statistics reinforce the importance of the question as to whether the legislation, and the obligations it seeks to impose on employers and public agencies, has substantive as opposed to simply symbolic value. The analysis here will show that while the problems are significant, solutions may also be at hand.

\section{Who Should be Eligible for Whistleblower Protection?}

The answer to the question of which persons should be eligible to receive the protective measures available under whistleblowing legislation appears obvious - the legislation is intended, among other things, to protect 'whistleblowers'. However, none of Australia's current legislative instruments defines the term 'whistleblower' or 'whistleblowing' - not even the four Acts (SA, Qld, Cth, $\mathrm{Vic})$ that use 'whistleblower protection' in their title or the relevant provision. Instead, true to the title of the remainder of the laws, their core subject is more properly identified as the making and handling of:

- ' 'public interest disclosures' - SA, Qld, ACT (1), Cth (2), WA, ACT (2); or

- 'protected disclosures' (NSW); or

- both 'protected disclosures' and 'public interest disclosures' (Vic, Tas, NT).

The titles of most laws are a reminder that whistleblower protection is being pursued not just for the individuals concerned, but because of its wider public importance. The protection of whistleblowers from reprisals is not just a matter of individual justice, but is instrumental in encouraging and facilitating disclosures that are in the public interest. Thus the formal objects of existing laws are relatively clear and consistent, reflecting what the New South Wales Ombudsman has described as the three 'almost universal pre-requisites' that need to be fulfilled before most employees will make a disclosure about problems in their organisation: ${ }^{11}$

1 to facilitate public interest disclosures - that is, to encourage whistleblowing;

2 to ensure that disclosures by whistleblowers are properly dealt with - that is, properly assessed, investigated and actioned; and

3 to ensure the protection of whistleblowers from reprisals taken against them as a result of their having made the disclosure.

There are good reasons why the terms 'whistleblower' and 'whistleblowing' are not used in legislation. The principal one is that the term is incapable of precise legal definition, being subject to so many public stereotypes — some of them mutually exclusive — as to defeat meaningful legal interpretation. While the presumption in this article is that public-interest whistleblowing has a fundamentally positive social purpose, the term is not a label with which even many whistleblowers are comfortable, as it also carries negative connotations of disloyalty, 'dobbing' or simply being 'singled out' in a

NSW Ombudsman (2004). For further analysis of key factors in a positive reporting climate, see Brown et al (2004). 
way that most employees would prefer to avoid. Further, on some definitions, whistleblowing is associated not only with the act of disclosure, but with the real or perceived suffering that some whistleblowers experience at the hands of their organisation as a result. ${ }^{12}$ On this definition, a whistleblower is only identified as such after they have suffered a reprisal or come into conflict with management over their disclosure, which would defeat the purpose of any whistleblowing legislation intended to protect them by preventing such conflicts.

In public policy and the social sciences, there is nevertheless an accepted definition of whistleblowing that accurately describes what these laws are about:

the disclosure by organisation members (former or current) of illegal, immoral, or illegitimate practices under the control of their employers, to persons or organisations that may be able to effect action. ${ }^{13}$

While current whistleblowing laws are without doubt framed with this definition in mind, the degree of confusing variation between them is highlighted by the fact that, of the existing public sector laws, only three operate in a manner which is fully consistent with this definition: the Protected Disclosures Act 1994 (NSW), section 16 of the Public Service Act 1999 (Cth) and the Public Interest Disclosures Act 2002 (Tas). These laws only apply to disclosures about public sector wrongdoing that are made by people who are 'organisation members' of, or internal to, the public sector, being employees of public sector agencies (usually defined as a 'a public officer' or 'public official'). The main whistleblowing provisions in the private sector also function in the same way - for example, Part 9.4AAA of the Corporations Act 2001 (Cth) concerns disclosures by the officers, employees or contractors of companies about breaches of the Corporations Act by or within their own company. ${ }^{14}$

By contrast, the remaining Acts or Bills listed in Table 1 provide that, in at least some circumstances, 'any person' may make a disclosure - irrespective of whether they hold a position that is internal to the organisation concerned. Queensland's Whistleblower Protection Act 1994 is a hybrid, in which sections 19 and 20 only allow disclosures by public officers in most instances, but in some circumstances also open the procedures to 'anybody'. The remaining laws can be triggered entirely by a disclosure by 'any person' or 'a natural person'. ${ }^{15}$

12 De Maria (1999), p 25.

13 Near and Miceli (1985), pp 1-4. This definition was also adopted in the report of the Senate Select Committee on Public Interest Whistleblowing (1994).

14 Part 9.4AAA, 'Protection for Whistleblowers', was introduced into the Corporations Act 2001 (Cth) by the Corporate Law Economic Reform Program (Audit Reform and Corporate Disclosure) Act 2004 (Cth).

15 See Public Interest Disclosure Act 1994 (ACT), s 15 ('[a]ny person'); Public Interest Disclosure Bill 2006 (ACT), cl 15 (a 'person'); Whistleblowers Protection Act 2001 (Vic), s 5 ('natural person'); Public Interest Disclosure Act 2003 (WA), s 5 ('any person'); Public Interest Disclosure Bill 2006 (NT), cl 7 ('a person'). 
Under these provisions, there is no requirement for an institutional or employment connection between the complainant and the organisation or wrongdoers about which they are complaining.

As the earlier definition suggests, an institutional or employment connection is in fact crucial to the position of a whistleblower for two reasons. First, it is because of their internal position that whistleblowers have information which is so worthy of disclosure. Other complainants who are members of the public only rarely have the same access to information and insights. Second, and most importantly, it is because they are internal that whistleblowers require special legal and management protection and special encouragement to come forward. Other persons, such as members of the public making complaints of wrongdoing in respect of services or matters that affect them as consumers, do not usually need the same level of legislative protection before they will report because they are not normally subject to the same organisational loyalties and risks of reprisal that affect an organisation's own employees.

This confusing state of affairs resulted from policy arguments in the 1990s that whistleblower protection was not only needed in the public sector, because anyone could potentially need to blow the whistle, including about private companies. Consequently, parts of the South Australian and Queensland legislation also apply to the disclosure of certain types of wrongdoing in the private sector, as will be discussed later in the article. Even there, however, an appropriate definition was never found, because there is no requirement that the person making the disclosure is internal to the private company involved they may equally be an aggrieved customer or an external public interest group. In the other instances, including under current ACT, Victorian and Western Australian law, even though the law only pertains to disclosures about wrongdoing in the public sector, any person including any member of the public may still make the disclosure. In Victoria, this may also be because, prior to its 2001 legislation, there was no mechanism for public complaints regarding serious corrupt or improper conduct by public officials of the kind readily found in other jurisdictions, and accordingly its whistleblowing law enabled two birds to be addressed by the one stone.

Whatever the reasons, this first major inconsistency in approach highlights the extent of the need for reconsideration and reform. There is little question that where it appears, the provision for 'any person' to be able to make a disclosure as if they were a whistleblower - including those who are not dilutes the purpose and focus of the legislation, confuses its operation, and leads to other problems such as narrowed interpretations of the type of matters that can be reported in order to control or prevent floods of disclosures from public complainants. The reputation of the legislation suffers because it can be used by complainants who are not actually whistleblowers, as an alternative avenue for pursuing non-whistleblowing grievances. Such complainants themselves may end up unhappy, because the legislation was never actually designed to help them but also gave a strong illusion that it could.

The solution to this issue has two elements. Those laws that currently provide 'open standing' for the making of disclosures should return to the 
original goal of whistleblower protection by providing that it is only employees or officials - and others who might properly be classified as 'internal' to the organisation concerned - whose disclosures may trigger the Act. However, it should equally be recognised that other complainants are entitled to protection against reprisals or harassment for having made their complaint; simply that this is not best provided for in legislation intended to protect whistleblowers. Instead, standard provisions in other legislation such as the criminal code or the enabling legislation of investigative agencies should ensure that it is an offence to harass or intimidate any complainant or witness in a manner consistent with offences relating to perversion of the course of justice. This does not require the same sorts of detailed systems and legal mechanisms needed to encourage public interest whistleblowing, such as discussed later in the article.

At the same time, even though it needs to be made more precise in many instances, care needs to be taken to ensure that all appropriate categories of 'organisation member' consistent with the above definition of whistleblowing are covered by the law. For example, under those public sector provisions where the law is limited to public officials, there is variability in the types of officials included - at a Commonwealth level, it is currently only employees of Australian Public Service (APS) agencies, which is only around half of all Commonwealth officials. Just as importantly, the law needs to expressly include contractors, employees of contractors, some categories of volunteers, and persons formerly in these categories if they may still be subject to organisational loyalties or pressures that would continue to prevent them from disclosing. While still narrow, current best practice in recognition of the position of contractors is found in Tasmania's public sector law, ${ }^{16}$ and in the private sector, where Part 9.4AAA of the Corporations Act 2001 (Cth) expressly includes both contractors to the relevant company and the employees of contractors. ${ }^{17}$

Finally, there is also variability in the extent to which protections under the legislation extend to third parties who might be at risk of reprisals as the result of someone having blown the whistle, in addition to the actual whistleblower. The term 'internal witness' was developed in the 1990s by the New South Wales Police Service ${ }^{18}$ to describe not simply whistleblowers (often presumed to mean only those officials who made the disclosure which triggered the matter), but others whose disclosures are made in evidence to an investigation which might have been triggered in another fashion, and who are still exposed to reprisal risks. While this term does not, and probably need not, appear in legislation, there are means of ensuring that the definition of disclosure covers

16 Public Interest Disclosures Act 2002 (Tas), s 6(2) provides that 'a contractor' may disclose improper conduct by 'a public body with which the contractor has entered into a contract', while s 3(1) defines 'contractor' to mean 'a person who at any time has entered into a contract with a public body for the supply of goods or services to, or on behalf of, the public body'. For a full checklist of persons who may need protection, see Brown (2006), pp 9-13.

17 Corporations Act 2001 (Cth), s 1317AA(a) also applies to (iii) 'a person who has a contract for the supply of services or goods to a company' and (iv) 'an employee of a person who has a contract for the supply of services or goods to a company'.

18 See Royal Commission into NSW Police Service (1997), p 402. 
such evidence. A major purpose of the legislation is to criminalise reprisals against those who make disclosures, but the offences created also need to cover reprisals taken against friends or family members of persons who disclose, or mistakenly against a third party that a victimiser suspects was the whistleblower even though they were not. While the Commonwealth public sector regime does not create any criminal sanctions, the New South Wales Protected Disclosures Act 1994 is also problematic in this regard. ${ }^{19}$

\section{What Types of Wrongdoing May be Disclosed?}

The second major inconsistency, confirming the need for comprehensive reform of current laws, is the extent of difference in the types of wrongdoing about which disclosures can be made that trigger the relevant legislation. Table 3 sets out the allowable subject-matter of disclosures under current public sector Acts and Bills, ranging from extremes of generality to quite narrow, serious definitions of misconduct. The table highlights how the relevant definitions of wrongdoing are often tied to existing definitions in other legislation, such as the Ombudsman Act or general anti-corruption legislation that applies in the jurisdiction. In most instances, the public interest disclosure law does not create an entirely new investigative regime unique to whistleblowing, but rather adds whistleblowing-related obligations and procedures to issues of public integrity already dealt with by a range of agencies.

The most general wording in the public sector is a current ACT proposal to redefine public interest disclosure to mean, literally, any 'conduct contrary to the public interest' ${ }^{20}$ This is significant because it again takes the legislation outside the realm of whistleblowing to also apply to employees or others who wish to simply 'speak up' about how an agency should better serve the public interest. Given competing views of the 'public interest' and the fact that many policy disputes and personal grievances are capable of being brought within this term, this legislative approach would probably be extremely difficult to administer. On the other hand, the approach in the remainder of the legislation runs the risk of creating definitions that may be too narrow. In all cases, unlawful behaviour is explicitly or implicitly included, as are corruption and other serious misconduct. Other categories of wrongdoing are sometimes omitted.

$19 \quad$ Protected Disclosures Act 1994 (NSW), s 20(1) provides that a reprisal is only an offence when taken against 'another person', substantially in reprisal for that 'other person' making a protected disclosure.

20 Public Interest Disclosure Bill 2006 (ACT), cl 8. 
Table 3: What types of wrongdoing can be the subject of disclosures?

\begin{tabular}{|c|c|c|c|c|c|c|c|}
\hline \multicolumn{2}{|c|}{ Legislation } & \multirow{2}{*}{$\begin{array}{r}\begin{array}{l}\text { Illegal } \\
\text { activity }\end{array} \\
\text { Yes }\end{array}$} & \multirow{2}{*}{$\begin{array}{c}\begin{array}{l}\text { Corrupt/official } \\
\text { misconduct }\end{array} \\
\text { (Yes) }\end{array}$} & \multirow{2}{*}{$\begin{array}{l}\text { Misuse/wast } \\
\text { e public } \\
\text { resources } \\
\text { Yes }\end{array}$} & \multirow{2}{*}{$\begin{array}{l}\begin{array}{l}\text { Maladmin } \\
\text {-istration }\end{array} \\
\text { Yes }\end{array}$} & \multirow[t]{2}{*}{\begin{tabular}{|l} 
Danger to \\
public health \\
or safety
\end{tabular}} & \multirow[t]{2}{*}{$\begin{array}{l}\text { Danger to } \\
\text { environment }\end{array}$} \\
\hline 1. & SA 1993 & & & & & & \\
\hline & Threshold? & \multicolumn{6}{|c|}{ No } \\
\hline \multirow[t]{2}{*}{2.} & Qld 1994 & (Yes) & Yes & Yes & Yes & \multicolumn{2}{|c|}{ Yes } \\
\hline & Threshold? & & $\begin{array}{l}\text { Criminal or } \\
\text { dismissable }\end{array}$ & \multicolumn{4}{|c|}{ No } \\
\hline \multirow[t]{2}{*}{3.} & NSW 1994 & (Yes) & Yes & Yes & Yes & & \\
\hline & Threshold? & & $\begin{array}{l}\text { Criminal, } \\
\text { disciplinary or } \\
\text { dismissable }\end{array}$ & \multicolumn{4}{|c|}{ No } \\
\hline \multirow[t]{2}{*}{4.} & $\begin{array}{l}\text { ACT (1) } \\
1994\end{array}$ & (Yes) & Yes & Yes & & Yes & \\
\hline & Threshold? & & $\begin{array}{l}\text { Criminal, } \\
\text { disciplinary or } \\
\text { dismissable }\end{array}$ & \multicolumn{4}{|c|}{ No } \\
\hline \multirow[t]{2}{*}{5.} & Cth(1) 1999 & Yes & Yes & Yes & Yes & & \\
\hline & Threshold? & \multicolumn{6}{|c|}{ No } \\
\hline \multirow[t]{2}{*}{6.} & $\begin{array}{l}\text { Cth (2) Bill } \\
2002\end{array}$ & (Yes) & Yes & Yes & & Yes & \\
\hline & Threshold? & & $\begin{array}{l}\text { Criminal, } \\
\text { disciplinary or } \\
\text { dismissable }\end{array}$ & \multicolumn{4}{|c|}{ No } \\
\hline \multirow[t]{2}{*}{7.} & Vic 2001 & (Yes) & Yes & Yes & & Yes & Yes \\
\hline & Threshold? & \multicolumn{6}{|c|}{ Criminal or dismissable } \\
\hline \multirow[t]{2}{*}{8.} & Tas 2002 & (Yes) & Yes & Yes & & Yes & Yes \\
\hline & Threshold? & \multicolumn{6}{|c|}{ Criminal or dismissable } \\
\hline \multirow[t]{2}{*}{9.} & WA 2003 & Yes & Yes & Yes & Yes & \multicolumn{2}{|c|}{ Yes } \\
\hline & Threshold? & \multicolumn{6}{|c|}{ No } \\
\hline \multirow[t]{2}{*}{10.} & NT Bill 2006 & (Yes) & Yes & Yes & & Yes & Yes \\
\hline & Threshold? & \multicolumn{6}{|c|}{ Criminal or dismissable } \\
\hline \multirow[t]{2}{*}{11.} & $\begin{array}{l}\text { ACT (2) Bill } \\
2006\end{array}$ & \multicolumn{6}{|c|}{$\leftarrow$ Yes $\rightarrow$} \\
\hline & Threshold? & \multicolumn{6}{|c|}{ No } \\
\hline 12 & $\begin{array}{l}\text { Cth (3) Bill } \\
2007\end{array}$ & \multicolumn{6}{|c|}{$\leftarrow$ Yes $\rightarrow$} \\
\hline
\end{tabular}


The most glaring deficiency in the ACT, Victoria, Tasmania and proposed in the Northern Territory is the omission of any facility for protection of disclosures about 'maladministration' or 'defective administration', 21 even though this is the only heading under which much wrongdoing relating to general organisational incompetence or mismanagement might be identified, and even though, in these jurisdictions, it is the Ombudsman who is charged with overseeing the investigation of disclosures.

The most startling inconsistency between existing public sector laws, however, relates to the standard of seriousness that a matter must meet before the disclosure comes within the Act and the whistleblower is protected. In addition to substantive types of wrongdoing, Table 3 shows whether or not the disclosure must also meet a particular criminal or disciplinary 'threshold' in order to qualify for protection. Some legislation (eg South Australia and Western Australia) applies no such additional threshold. However, these thresholds apply in respect of disclosures about 'official misconduct' in Queensland, and 'corrupt conduct' in New South Wales. This is because, in each instance, the definition of this particular type of conduct is supplied not by the whistleblowing law but by another Act, in which the statutory test for the conduct has two parts - one relating to substantive behaviour (eg breach of public trust, favouritism, partiality) and the other to the fact that it must also be sufficiently serious to breach existing recognised criminal or disciplinary standards. ${ }^{22}$ Consequently, disclosures about official misconduct or corrupt conduct in these states have to concern a criminal offence, a disciplinary offence or a matter capable of justifying the dismissal of a public official, before the disclosure comes within the Act. Disclosures about other forms of wrongdoing, such as defective administration, waste of public funds, or threats to public and health and safety, do not have to meet such a threshold.

However, as Table 3 shows, a more restrictive approach applies in Victoria, Tasmania and the originally proposed Northern Territory regime (each of the latter being based on the Victorian precedent). There, all disclosures must meet the test of showing conduct that would, if proved, constitute either 'a criminal offence' or 'reasonable grounds for dismissing or dispensing with, or otherwise terminating, the services of a public officer who was, or is, engaged in that conduct'. ${ }^{23}$ This includes not only corrupt or official misconduct, but alleged wrongdoing involving public wastage, organisational negligence or systemic failures which far more rarely results in any individual being identified as

$21 \quad$ Public Interest Disclosure Act 1994 (ACT), ss 3, 4; Whistleblowers Protection Act 2001 (Vic), s 3(1); Public Interest Disclosure Act 2002 (Tas). s 3(1); Public Interest Disclosure Bill 2006 (NT), cl 4(1).

22 See Whistleblowers Protection Act 1994 (Qld), s 15, importing Crime and Misconduct Act 2001 (Qld), ss 15, 16 ('official misconduct'); Protected Disclosures Act 1994 (NSW), s 10, importing Independent Commission Against Corruption Act 1988 (NSW), ss 8(1) and 9(1) ('corrupt conduct').

23 Whistleblowers Protection Act 2001 (Vic), s 3(1)(e) and (f); Public Interest Disclosures Act 2002 (Tas), s 3(1)(e) and (f); Public Interest Disclosure Bill 2006 (NT), cl 4(1)(e) and (f). 
sufficiently culpable to be sacked or charged with a criminal offence, but which may nevertheless involve seriously defective practices and procedures.

The explanation for this defect is the Victorian drafting decision, at a time when the whistleblowing law also created systems for the investigation of corrupt and official misconduct that the state did not previously possess. Consequently, the criminal and disciplinary thresholds were applied to all prospective public interest disclosures, rather than simply the specific types to which they applied in New South Wales, Queensland and other jurisdictions. Part of the restrictiveness of this result may have been calculated to achieve another means of controlling an anticipated 'floodgate' of disclosures resulting from the equally problematic decision to open the legislation to any natural person, as discussed in the previous section. However, even if that is the case and quite apart from the fact that no such flood has ever eventuated - the approach appears to threaten the entire utility of the Act in many instances. Not only is there a major case for ensuring that all public law jurisdictions adopt a more consistent and comprehensive approach to the categories of wrongdoing that justify a public interest disclosure, but there is a particular case for reviewing the severe thresholds that apply in any legislation following the Victorian model.

The adoption of definitions of wrongdoing based on other public integrity legislation is an approach that is now also being replicated in the private sector. Just as whistleblower protection under public law accompanies the regulatory jurisdiction of specific agencies for specific purposes (Ombudsman for maladministration, Auditor-General for public wastage, and so on), so too protections in the private sector only attach to certain wrongdoing for certain purposes. Part 9.4AAA of the Corporations Act 2001 (Cth) accompanies the jurisdiction of the Australian Securities and Investments Commission (ASIC), and only covers disclosures to directors, managers, auditors or ASIC regarding breaches of the 'Corporations legislation'. ${ }^{24}$ While the range of matters that might amount to a breach of directors' duties is now wide, there is no express facility to disclose illegality in general, or such matters as corruption, waste, dangers to public health or safety, defective or fraudulent products, or breach of environmental, tax, trade practices or workplace relations laws. Similarly, identical provisions also inserted into the Workplace Relations Act 1996 (Cth) do not extend whistleblower protection to all employees who might allege wrongdoing within the control of their employer, but rather only officers, employees and members of registered organisations (ie trade unions and

24 Corporations Act 2001 (Cth), s 1317AA(1)(d). 'Corporations legislation' is defined in s 9 to mean the Corporations Act, the Australian Securities and Investments Commission Act 2001 (Cth) (hereafter the ASIC Act) and the rules of court. Section 1317AA(2) provides that 'A reference in subsection (1) to a person contravening a provision of the Corporations legislation includes a reference to a person committing an offence against, or based on, a provision of this Act. Note: This subsection causes section 11.6 of the Criminal Code to operate in relation to such references.' As pointed out in the Explanatory Memorandum (House of Representatives 2004), 5.390, the application of the Criminal Code will also extend the protection afforded under the Part to disclosures made in relation to attempts, incitement or conspiracy to breach the law. 
employer associations) who disclose breaches of the Act. ${ }^{25}$ These amendments were partly motivated by the recommendations of the Cole Royal Commission Report on the Building and Construction Industry, which had drawn attention to unacceptable work practices that were calling for disclosure. ${ }^{26}$ However, the type of wrongdoing that can be reported is narrow, again tied specifically to the jurisdiction of those agencies charged with oversighting the integrity of the workplace relations system itself, such as the employment advocate or office of workplace services. The fact that private sector legislation has moved in parallel with the somewhat fragmented 'regulatory' approach to whistleblowing in the public sector raises significant issues for how a more comprehensive approach to whistleblower protection might be attempted, as discussed in the last part of the article.

\section{When Should Public Whistleblowing be Protected?}

While the above two major areas of inconsistency emphasise the need for a comprehensive approach to reform, the next two issues demonstrate that reform needs to seriously re-engage with the fundamental reasons for having any public interest disclosure legislation.

The first of the two major gaps we wish to emphasise is the fact that, currently, only one of the many legislative regimes dealing with whistleblower protection extends the legal effects of the Act to disclosures made outside official channels - to the media or other third parties. This is despite the fact that whistleblowing to the media is the archetypal, and best-known, example of the practice; and the fact that clearly, in some instances, it is only exposure by the media (or the risk thereof) that leads authorities to appreciate the seriousness of some matters and to take action. It is widely accepted that 'leaks, and whistleblowers, are essential to a proper democratic system'. ${ }^{27}$ Some commentators argue that unless they have this public quality, disclosures should not be defined as 'whistleblowing' at all. ${ }^{28}$ Perhaps most significantly, some of the basic legal protections provided by public interest disclosure laws are framed specifically with public whistleblowing in mind. One of the basic reasons for such laws is to remove what would otherwise be major legal barriers to whistleblowing in the form of the risk of disciplinary, termination, criminal or civil action either for breach of confidence by an employee, or defamation of the organisation or individuals involved. Every law is consistent in providing indemnity from any action for breach of confidence, and either a qualified or absolute privilege in respect of civil action such as defamation. ${ }^{29}$ Why such

25 Part 4A (ss 337A-337D) ('Protection for whistleblowers') was added by Schedule 1, Chapter 11 of the Workplace Relations Act 1996 (Cth) in 2004, two weeks after the Corporations Act amendments, by the Workplace Relations Amendment (Codifying Contempt Offences) Act 2004 (Cth), in force 13 July 2004.

26 Murray (2003).

27 Oakes (2005).

$28 \quad$ Grace and Cohen (1998), p 150. 
defences are needed, if the legislation also does not contemplate that it is permissible for such matters to ever be made public, is something of a mystery.

Currently, the only legislation to contemplate public whistleblowing is the New South Wales Protected Disclosures Act 1994, which provides for a disclosure to a 'journalist' to be protected in certain circumstances. ${ }^{30}$ Not even all legislation provides for disclosure to a member of parliament. ${ }^{31}$ The New South Wales provisions require that legal protection will extend to such a public disclosure where the whistleblower has first made the disclosure internally or to a relevant investigating authority, but the relevant authority has either (a) decided not to investigate, (b) decided to investigate but not completed the investigation within six months, (c) investigated but not recommended the taking of any action, or (d) failed to notify the person making the disclosure, within six months, whether or not the matter is to be investigated. ${ }^{32}$ Under this regime, the whistleblower must also have reasonable grounds for believing the disclosure is 'substantially true', and it must indeed be substantially true...$^{33}$ In other words, it must be reasonable for the whistleblower to persist with the matter to the point of taking it into the public domain, and there must be some independent reason to believe that the additional public disclosure is vindicated.

These provisions are themselves not unproblematic in principle and practice. However, even more problematic has been the failure of any other Australian parliament to even grapple with the issue of public whistleblowing. In some respects this failure is, of course, politically understandable, reflecting the natural apprehension felt by all governments in relation to the extension of legal protection to the public whistleblower, since publicity creates the highest conflict between individuals and organisations and highest risk to political reputations. Yet if there are no provisions to distinguish between the two, public whistleblowing can easily be confused with simple 'leaking' — which includes unauthorised disclosure of official information for a wider range of reasons including those less related to any objective public interest, such as blatantly party-political or corrupt reasons. Accordingly, particularly at the Commonwealth level under the former Howard

29 See, for example, Whistleblowers Protection Act 1993 (SA), s 5(1); Whistleblowers Protection Act 1994 (Qld), s 39; Protected Disclosures Act 1994 (NSW), s 21; Public Interest Disclosure Act 1994 (ACT), s 35; Whistleblowers Protection Act 2001 (Vic), s 14; Public Interest Disclosures Act 2002 (Tas), ss 16-17; Public Interest Disclosure Act 2003 (WA), s 13; Public Interest Disclosure Bill 2006 (NT), ss 16-17; Public Interest Disclosure Bill 2005 (ACT), s 49; Corporations Act 2001 (Cth), s 1317AB; Workplace Relations Act 1996 (Cth), Sch 1,Ch 11, Pt 4A, s 337B.

$30 \quad$ Protected Disclosures Act 1994 (NSW), ss 8(1)(d), 19(1). A journalist is 'a person engaged in the occupation of writing or editing material intended for publication in the print or electronic news media': s 4.

31 See, for example, Protected Disclosures Act 1994 (NSW), s 19(1); Whistleblowers Protection Act 1994 (Qld), ss 26(1)(b), 27(3) and Sch 5, s 2(1)(a); and ss 26(1A), 28A as introduced by the Whistleblowers (Disclosure to Member of Parliament) Amendment Act 2007 (Qld). See also Whistleblowers Protection Act 1993 (SA), s 4 'public officer', cl (b); Whistleblowers Protection Act 2001 (Vic), s 6(2), Whistleblowers Protection Regulations 2001 (Vic), r 6.

32 Section 19(3).

33 Sections 19(4) and (5). 
Coalition government, such disclosures tended to meet with vigorous investigation and prosecution even when they had a well-established public interest element. ${ }^{34}$ The most notable case was the 2006-07 prosecution of an Australian Customs official Alan Kessing for (allegedly) releasing information to the media regarding unaddressed security weaknesses at Sydney Airport. ${ }^{35}$

However, the impetus to revisit this legislative element has gained substantial strength in two jurisdictions. In Queensland in 2004-05, effective action to recognise and deal with serious medical negligence in the Bundaberg Hospital only occurred after a nursing manager disclosed her concerns to her local parliamentarian (a member of the opposition), who then made them public. The nursing manager, Toni Hoffman, had previously raised her concerns internally, but the internal response proved woefully ineffective. Had it not been for the media interest, including the investigative journalism that then exposed the full extent of the systemic breakdowns involved, it is unlikely that the matter would ever have been dealt with properly. ${ }^{36}$ As a result, the Bundaberg Hospital Commission of Inquiry (2005) recommended amendment of the Queensland legislation to reflect the principle that 'a whistleblower ought to be able to escalate his or her complaint' if satisfactory action is not taken, with a system of mandatory notification of disclosures to a central agency (the Ombudsman), accompanied by provisions allowing the whistleblower to take the disclosure to a Member of Parliament if an agency did not resolve a disclosure within 30 days, and then, after a further 30 days, to the media. ${ }^{37}$ While the Queensland government accepted the recommendation in respect of disclosures to Members of Parliament, it declined to act on the recommendation that disclosures should also be possible to the media. Nevertheless, the issue remains.

The second jurisdiction in which the issue has come alive, in a decided fashion, is the Commonwealth. Here - not least because of the prosecutions and related controversies already noted - the need to recognise the legitimacy of justified public whistleblowing forms the cornerstone of the new Rudd Labor government's commitment to introduce 'best practice' legislation:

Where a person has exhausted all legitimate mechanisms and avenues of complaint, and still finds that through the force of extreme circumstances they are obliged to disclose information to third parties such as journalists, protection by a court may still be provided dependent upon the circumstances. In situations where there may be compelling reason requiring disclosure, a court will be able to weigh up all the relevant factors and balance the public interest in disclosure against any breach of confidentiality which may have occurred. In these cases, there will be two key tests to determine when public interest disclosure will attract legal protection. Firstly, where the whistleblower has gone through the available official channels, but has not had success within a reasonable

\footnotetext{
Ester (2006), p 83.

35 Brown (2007), pp 19-28.

36 Thomas (2007).

37 Davies (2005), para 6.512, p 472.
} 
timeframe and, secondly, where the whistleblower is clearly vindicated by their disclosure. ${ }^{38}$

This commitment recognises that public whistleblowing is a legitimate course for organisation members who have either tried to raise an issue of wrongdoing through official channels without success, or cannot reasonably be expected to raise the matter through official channels for whatever reason, including lack of such a channel, or risk of reprisal. For these purposes, 'official channels' include internal whistleblowing within the organisation, or a disclosure to an external regulatory agency, or both. The common element of the approaches attempted in New South Wales, recommended in Queensland and now promised at the Commonwealth level is the idea of a 'stepped disclosure' regime in which legal protection may flow to a public whistleblower but only after avenues for internal or regulatory whistleblowing have already been exhausted.

While the principle is relatively clear, the current New South Wales provisions, Queensland proposal and even the Commonwealth commitment demonstrate the difficulty of finding an effective stepped public disclosure regime. In the New South Wales provisions and the Queensland proposal, the time limits involved are somewhat arbitrary - they may be either too long to be reasonable in some cases, or in others not long enough to enable proper investigation to occur. The Queensland proposal does not recognise the need for some assurance that the whistleblower has persisted with the matter because it is reasonable to do so, rather than because the whistleblower is simply obsessed, or worse - in which case extending an absolute defence from defamation action may not be in the public interest. Most importantly, however, both the New South Wales requirement and the terms of the Commonwealth commitment set a further very high bar that may be difficult even for most reasonable public whistleblowers to achieve - the requirement that the disclosure must be 'substantially true' in New South Wales, or that of 'clear vindication' in the Commonwealth case. These standards go significantly beyond any test as to whether it is objectively reasonable for a person to persist with a disclosure - a circumstance which might exist even if there is ultimately insufficient evidence to prove the matter alleged, or prosecute or convict a wrongdoer, or clear evidence as to 'vindication' as against reasonableness. Further, it is not clear who is to be the arbiter of whether the disclosure has been shown to be true, in the New South Wales case, or how the test of 'vindication' is to be otherwise satisfied. It would probably be the court or tribunal in which the whistleblower is seeking to defend himself or herself against defamation or criminal prosecution - but these are not forums suited to investigate the matter, and even if their disclosure was reasonable, many whistleblowers would struggle to conclusively prove the 'truth' of their disclosure in the face of opposing arguments and evidence.

It is likely that the solution will be found in the type of more flexible stepped disclosure regime provided by the United Kingdom's Public Interest

Rudd and Ludwig (2007), pp 8-9 
Disclosure Act 1998, which specifically provides for disclosures other than to the whistleblower's employer or a regulatory agency, where these are reasonable in all the circumstances, not made for personal gain, and meet one of four further preconditions. These require that either (a) the whistleblower must reasonably believe that they would be victimised if they made an internal or regulatory disclosure; or (b) there is no prescribed regulator and the whistleblower reasonably believes that evidence is likely to be concealed or destroyed unless the further disclosure is made; or (c) the concern has already been raised with the employer or a prescribed regulator, but not resolved, as described above; or (d) the concern must be of an exceptionally serious nature. ${ }^{39}$ Under these provisions, the assessments as to reasonableness are more open and flexible, since it is clear who will making them - the employment tribunal which is asked to enforce the protections under the Act by awarding compensation to any such whistleblower who has been unfairly treated. The stepped disclosure regime under the British regime is depicted in Figure 1.

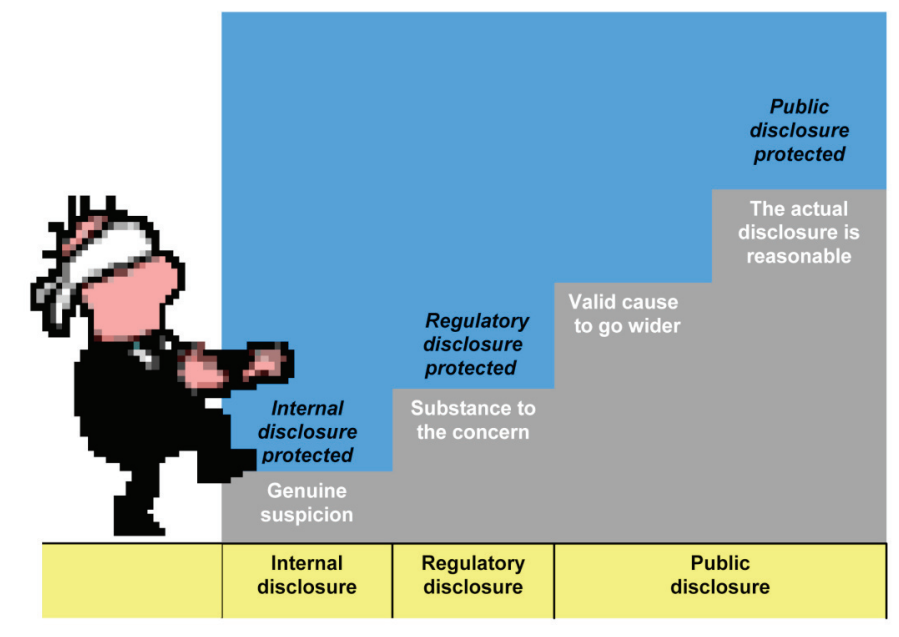

Figure 1: United Kingdom stepped disclosure regime ${ }^{40}$

The important advance, particularly at a Commonwealth level, is the recognition that Australian legislation can and should be extended to close this very conspicuous gap. However, rather than assuming that the type of approach taken in the New South Wales legislation is actually workable, there is a clear need for debate and deliberation on the principles of a sensible approach to

39 Employment Rights Act 1996 (UK), ss 43G and 43H, as inserted by Public Interest Disclosure Act 1998 (UK); see explanatory guide by Public Concern at Work, www.pcaw.co.uk.

$40 \quad$ Public Concern at Work, www.pcaw.co.uk. 
public whistleblowing. ${ }^{41}$ Until this occurs, wherever public interest disclosure legislation lacks a facility for protection of a whistleblower who has made the matter public in reasonable circumstances, it will remain difficult for that legislation to be regarded as comprehensive or credible.

\section{Effective Compensation for Aggrieved Whistleblowers}

The second major gap in Australian public interest disclosure legislation concerns not the circumstances in which legal protection flows to a whistleblower, but the nature and extent of that protection. Legal protection under the legislation typically takes three forms. As discussed in the previous section, whistleblowers need to be relieved of potential liability for their disclosure, such as the risk of disciplinary or criminal prosecution for unauthorised disclosure of information, or civil action such as defamation. As mentioned earlier, Australian legislation also routinely makes it a criminal offence for a person to undertake a reprisal against someone who has made a public interest disclosure, with only the Commonwealth government's current scheme currently lacking such a criminal sanction. Third, the legislation seeks to provide whistleblowers with civil, workplace or other remedies, so that those who suffer as a result of making a disclosure can seek redress or be compensated.

Effective compensation mechanisms are crucial not simply from the perspective of justice for individual whistleblowers, but because of their preventative effect, and the fact this effect bears directly on those in the best position to ensure that whistleblowers are not victimised - the management of organisations and agencies. While criminal sanctions also have a deterrent effect, the most effective legal mechanisms for ensuring that whistleblowing is appropriately managed are those that increase the likelihood that organisations themselves will take whistleblowing seriously, and consider the long-term impacts of actions that might amount to 'shooting the messenger' or failing to curb those inclined to take such actions. For this reason, an Australian Standard now exists setting out basic requirements for whistleblower protection systems in all medium to large organisations. ${ }^{42}$ In several instances, public sector legislation now requires each agency to put in place minimum procedures for protecting those who make disclosures, with best practice found in Western Australia's Public Interest Disclosure Act, which places a direct and positive obligation on the principal executive officer to "provide protection from detrimental action or the threat of detrimental action for any employee ... who makes an appropriate disclosure of public interest information' ${ }^{43}$

\section{Brown (2006), p 44.}

42 Standards Australia, Whistleblower Protection Programs for Entities (Australian Standard 8004-2003) (2003).

$43 \quad$ Public Interest Disclosure Act 2003 (WA), s 23(1)(b). Like the WA Act, the Whistleblowers Protection Act 2001 (Vic), s 68 and the Whistleblowers Bill 2006 (NT), cl 13 also require a central integrity agency to develop model procedures with which agency procedures must be consistent. By contrast, four public law jurisdictions have no statutory requirement for agency procedures to deal with this issue: Whistleblowers Protection Act 1993 (SA), Protected 
Underscoring the management obligations of agencies towards employees who report wrongdoing are a range of provisions providing whistleblowers who suffer detriment with a right to damages or other non-criminal remedies from whoever might be responsible. The problem with these provisions is that, as a general rule, they rely on a whistleblower being prepared to pursue damages in the form of a tort by mounting an action in the Supreme Court of their jurisdiction. ${ }^{44}$ This costly and potentially risky process, should the action fail, is one that no known whistleblower has taken up. In a leading Australian case, an officer of the New South Wales Police Service successfully sought compensation not under any whistleblowing legislation but under the common law of employment, alleging his employer breached its duty of care towards him by failing to protect him from discrimination and harassment in the workplace. ${ }^{45}$ Damages of $\$ 664270$ were awarded for breaches by the employer, including:

- 'failing to provide the plaintiff with a system of pro-active protection (which would include taking active steps to prevent or stop victimisation and harassment);

- $\quad$ failing to give support and guidance to the plaintiff;

- failing to provide the plaintiff with a form of proactive assistance (failing to appreciate that officers who are in need of welfare assistance very often do not realise that they need it, or they feel embarrassed about asking for it); and

- $\quad$ failing to assure the plaintiff that he had done the right thing.

The legal obligations of managers to protect whistleblowers are thus clear. The question is whether viable and realistic avenues currently exist for whistleblowers to enforce these obligations through the pursuit of damages or other remedies. Just as the New South Wales result was obtained under normal employment law rather than any specific provision for whistleblower protection, so too the United Kingdom regime relies entirely for its effectiveness on the facility it creates for whistleblowers to pursue damages through the national employment appeals tribunal system - the equivalent of Australia's workplace relations system. ${ }^{46}$ Importantly, damages may be pursued for actions short of dismissal - that is, any actions that breach the employer's duty of care;

Disclosures Act 1994 (NSW), the regime under the Public Service Act 1999 (Cth) and the Public Interest Disclosure Act 2002 (Tas).

$44 \quad$ See Whistleblowers Protection Act 1993 (SA), s 9(2)(a); Whistleblowers Protection Act 1994 (Qld), s 43(1); Public Interest Disclosure Act 1994 (ACT), s 29; Whistleblowers Protection Act 2001 (Vic), s 19(1); Public Interest Disclosures Act 2002 (Tas), s 20(2); Public Interest Disclosure Act 2003 (WA), s 15(1). The Protected Disclosures Act 1994 (NSW), s 24 provides no additional avenues for compensation beyond existing statutory and common law remedies. See also Corporations Act 2001 (Cth), s 1317AD; Workplace Relations Act 1996 (Cth), Sch 1, Ch 11, Pt 4A, s 337D.

45 Wheadon v State of NSW, District Court of NSW, No 7322 of 1988 (2 February 2001), discussed in NSW Ombudsman $(2005,2006)$, p B58.

46 Employment Rights Act 1996 (UK), s 48(1A) as inserted by Public Interest Disclosure Act 1998 (UK), s 3; see explanatory guide by Public Concern at Work, www.pcaw.co.uk. 
damages are uncapped; and compensation awards are assessed according to what is 'just and equitable in all the circumstances', having regard to the infringement complained of and any loss suffered by the worker as a result of the detriment. ${ }^{47}$ The maximum award to January 2003 was $£ 805000$ in the case of Bhatia v Sterlite Industries; however, in 2005-06, a year in which 1034 public-interest disclosure claims were lodged in the British employment tribunal system, a new maximum was set with an award of $£ 5$ million to two senior private sector whistleblowers. ${ }^{48}$

This approach is clearly sensible, not simply because a tribunal system is more flexible and generally less costly than a court action for a tort, but because it places the compensation mechanism squarely within the legal realm where the obligations to prevent such damage are clearest - those falling on an employer by virtue of the employment relationship. However, it contrasts strongly with current Australian legislation. As Table 4 shows, some public law legislation does also attempt to provide an alternative mechanism through antidiscrimination or equal opportunity tribunals. ${ }^{49}$ However the nature of this jurisdiction does not appear to make for a good 'fit' with the issues that confront whistleblowers, who are discriminated against not because of personal attributes (such as sex, age, race or disability) but rather because of their involvement in specific, complex events. Queensland is the only public law jurisdiction in Australia to explicitly provide an employment law remedy for whistleblowers, by way of complaint to the Industrial Commission, but even this is limited to an action for unfair dismissal. ${ }^{50}$ In no jurisdiction, therefore, does Australian law provide any streamlined avenue for seeking compensation for damage arising from breach of the employers' obligation to protect a whistleblower, based on any act or omission short of dismissal.

In an increasingly market-oriented society, one of the most efficient and reliable ways to ensure that managers are aware of their whistleblower protection obligations, and act to fulfil them, is by demonstrating the serious financial costs that could fall to the organisation if they fail to do so. It is in this respect that efficient compensation mechanisms have their desired preventative effect. While the mechanisms for preventing reprisals and detriment against whistleblowers can and should also be pursued in other ways, this area of reform offers perhaps the single greatest potential for helping Australian publicinterest disclosure laws achieve their aim of remediating serious adverse impacts where these prove unavoidable. It is also an issue that cuts across both the public and the private sectors, provoking some important issues for the shape of reform as discussed in the next section.

Employment Rights Act 1996 (UK), s 49(2).

48 Dehn (2006).

$49 \quad$ See Whistleblowers Protection Act 1993 (SA), s 9(2)(b); Whistleblowers Protection Act 1994 (Qld), s 45(1)(c); Public Interest Disclosure Act 2003 (WA), s 15(4).

50 Industrial Relations Act 1998 (Qld), s 73(2)(f)(i). In the private sector, see also now Corporations Act 2001 (Cth), s 1317AB(3); cf Workplace Relations Act 1996 (Cth), Sch 1, Ch 11, Pt 4A, s 337B. 
Table 4: Civil, industrial and equitable remedies

\begin{tabular}{|c|c|c|c|c|c|}
\hline \multicolumn{2}{|c|}{ Legislation } & $\begin{array}{l}\text { Civil } \\
\text { action } \\
\text { (tort) }\end{array}$ & $\begin{array}{l}\text { Equal opportunity/ } \\
\text { anti-discrimination }\end{array}$ & $\begin{array}{l}\text { Workplacel } \\
\text { employment law }\end{array}$ & $\begin{array}{l}\text { Injunctive } \\
\text { relief }\end{array}$ \\
\hline 1 & SA 1993 & $9(2)(a)$ & $\begin{array}{l}\text { 9(2)(b) Equal } \\
\text { Opportunity Act } 1984\end{array}$ & Nil & Nil \\
\hline 2 & Qld 1994 & 43 & $\begin{array}{l}45(1)(c) \text { unfair } \\
\text { treatment of the } \\
\text { officer }\end{array}$ & $\begin{array}{l}\text { Industrial } \\
\text { Relations Act } \\
\text { 1999, 73(2)(f)(i), } \\
\text { unfair dismissal }\end{array}$ & $\begin{array}{l}47,48,49, \\
50,53,54\end{array}$ \\
\hline & NSW 1994 & \multicolumn{4}{|l|}{ Nil } \\
\hline & $\begin{array}{l}\text { ACT (1) } \\
1994 \\
\end{array}$ & 29 & Nil & Nil & 30,31 \\
\hline & $\begin{array}{l}\text { Cth (1) } \\
1999\end{array}$ & Nil & $\begin{array}{l}\text { 16. victimisation or } \\
\text { discrimination }\end{array}$ & $\mathrm{Nil}$ & Nil \\
\hline & $\begin{array}{l}\text { Cth (2) Bill } \\
2002\end{array}$ & 30 & Nil & Nil & 31,32 \\
\hline 7. & $\begin{array}{l}\text { Vic } \\
2001\end{array}$ & 19 & Nil & Nil & 20,21 \\
\hline & $\begin{array}{l}\text { Tas } \\
2002 \\
\end{array}$ & 20 & Nil & Nil & 21,22 \\
\hline & $\begin{array}{l}\text { WA } \\
2003\end{array}$ & 15 & $\begin{array}{l}\text { 15(4) Equal } \\
\text { Opportunity Act } \\
1984\end{array}$ & Nil & Nil \\
\hline & $\begin{array}{l}\text { NT Bill } \\
2005\end{array}$ & 19 & Nil & Nil & 20 \\
\hline & $\begin{array}{l}\text { ACT (2) } \\
\text { Bill } \\
2006 \\
\end{array}$ & $53(3),(4)$ & $\begin{array}{l}53(5) \\
\text { Discrimination Act } \\
1991 \\
\end{array}$ & Nil & Nil \\
\hline & $\begin{array}{l}\text { Cth (3) Bill } \\
2007\end{array}$ & 21 & 22 & 22 & 23 \\
\hline
\end{tabular}

\section{Which Elements of Public and Private Sector Whistleblower Protection Might be Based in the Same Law?}

The final issue for consideration is the extent to which the reform of public interest disclosure legislation might benefit from a totally different approach to that presently taken when it comes to fundamental questions that cut across both the public and private sectors. As outlined earlier in the article, it has long been recognised in Australia that public-interest whistleblowing is not confined to either sector. Consequently, it has often appeared that it would be attractively simple to have a single national legislative regime dealing with all aspects of whistleblowing. ${ }^{51}$

\footnotetext{
See Senate Select Committee on Public Interest Whistleblowing (1994).
} 
However, in the two early instances where attempts have been made to deal with some aspects of public and private sector whistleblowing together, the results are generally not regarded as satisfactory. In South Australia, in addition to a range of matters specific to the public sector, the law covers disclosures by any person about any 'illegal activity', whether within public agencies or private companies. $^{52}$ However, this has proved problematic because, as discussed earlier, it also goes beyond whistleblowing to include anyone who provides information about unlawful activity - for example, normal victims of crime, and criminal complainants and informants. It also requires the law to deal with the question of protection at a high level of generality, compared with the specific obligations and procedures that are triggered by disclosures under the legislation in every other state. In Queensland, these specific obligations and procedures apply to some private sector whistleblowing, but only narrow categories: dangers to the environment or the health or safety of persons with disabilities. ${ }^{53}$ Again, despite the title of the Act, those protected are 'anybody' and not simply whistleblowers.

Accordingly, all other public law jurisdictions have simply confined their legislation to disclosures regarding wrongdoing within the public sector. As noted previously, private sector whistleblower protection has begun to parallel this, being confined in first instance to breaches of national corporations legislation. These developments highlight some of the fundamental reasons why public and private sector whistleblowing currently seem to be following separate tracks. The trend is towards detailed legislation specifying not only the principles of whistleblower protection, but procedures for the making and investigation of disclosures, and the responsibilities of agencies and investigative authorities. These details vary from jurisdiction to jurisdiction including not just each public law jurisdiction, which is organised according to the federal system, but each area of private sector regulation. Even though these increasingly tend to be organised nationally, precise responsibilities and procedures vary between regulatory regimes (for example, company regulation, investor and shareholder protection, consumer and environmental protection). If the detailed approach continues to be followed, then these provisions will be equally difficult to combine under one law.

Nevertheless, as demonstrated by the first two issues set out in this article, this detailed, regulatory-based approach has resulted in problems of fragmentation and inconsistency that are difficult to remedy, and work to confuse and confound those concerned with achieving the efficient protection of public interest whistleblowers in practice. There appears to be a strong case for recalling the fundamental first principles of whistleblower protection, and finding legislative strategies to operationalise these in simple ways, irrespective of organisational context. This is because, notwithstanding the different detailed legislation that now applies, many of the fundamental aspects of whistleblowing and whistleblower protection remain rooted in the common law. Even if it were desirable to delineate a neat public-private sector-blind divide in the

Whistleblowers Protection Act 1993 (SA), s 4.

Whistleblowers Protection Act 1993 (Q1d), ss 18 and 19. 
formulation of whistleblower protection laws, this divide has already been breached.

In the public sector, for example, the courts have always accepted that the public interest in the disclosure of crimes or corruption can outweigh official obligations to preserve confidentiality. In Canada, the courts have given priority to the freedom of expression of a public servant whistleblower over their duty of loyalty in two situations, wherever (1) the government is engaged in acts that are illegal, or jeopardise the life, health, or safety of the public; and (2) the disclosure does not impact on a public servant's ability, or the public perception of their ability, to perform their duties. ${ }^{54}$ Similar principles have recently been endorsed by the European Court of Human Rights..$^{55}$ In Australia, too, while the duty of loyalty is often currently regarded as paramount, ${ }^{56}$ it cannot impose unquestioning silence. Consistently with the freedom of communication that can be found implied in the Australian Constitution, ${ }^{57}$ the Federal Court in Bennett $v$ President, Human Rights and Equal Opportunity Commission found that formal public service regulations outlawing the disclosure of official information did not necessarily prevent the lawful disclosure of information that was in the public interest. $^{58}$

In the private sector, similarly, the move towards legislation is best understood as complementing and codifying principles that have always been discoverable at common law. For example, the professional roles of accountants have always carried recognised obligations that surpass the loyalty of the individual to any one organisation: 'While they are not expected to become martyrs, accountants are expected to respond appropriately to behaviour that breaches the law.' ${ }^{59}$ There is authority that a financial services compliance officer will not be in breach of a duty of confidentiality if they report breaches of law to an industry self-regulator or taxation authorities. ${ }^{60}$ In banking, a bank's duty to maintain confidentiality in respect of its customers' financial affairs ${ }^{61}$ is subject to well-known exceptions including duties to disclose under compulsion of law and where it is in the public interest. ${ }^{62}$ While there has been a recent focus on strengthening statutory recognition of these issues in the Corporations Act

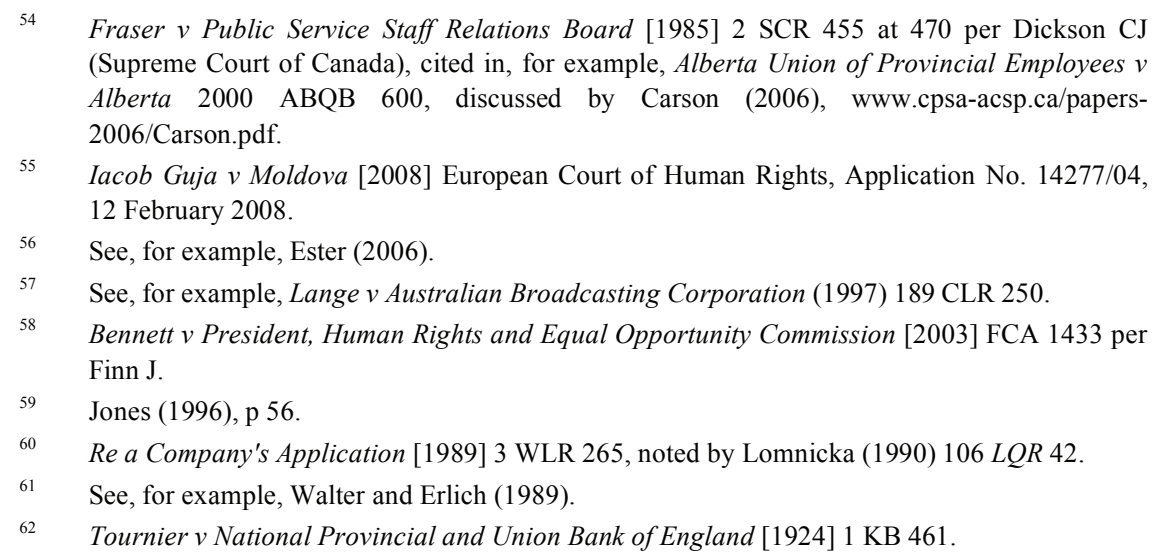


2001 (Cth), and the United States' Sarbanes-Oxley Act, ${ }^{63}$ in fact financial services legislation has existed for decades requiring disclosure by auditors of corporate fraud and misconduct. ${ }^{64}$

In both the public and private sectors, the bulk of the detail of new legislation has been concerned with strengthening and codifying these already well-recognised principles. What this analysis has highlighted is that codification of when and how public interests disclosures may be made, and when and how they should be investigated, does not directly extend to effective whistleblower protection. While the common law of employment does carry with it an obligation to protect employees who report wrongdoing, the previous section showed that the codification of this obligation has received fairly scant attention in Australia, despite the relative explosion of whistleblower 'protection' legislation. It is this obligation that, as has occurred in the United Kingdom, is most clearly best pursued as a question of general law applying to all employers whether they lie in the public or private sector.

The question that now arises in Australia, therefore, is not whether multiple jurisdictional laws dealing with whistleblowing will continue to exist. Given the reliance now placed on the detailed procedures set out in such laws across a spectrum of public and private sector regulation this particular clock is unlikely to be turned back. ${ }^{65}$ The new question is whether employers' legal obligations to protect whistleblowers, discussed in the previous part, are also to be extended piecemeal, or would be more efficiently codified in a general fashion that overlays and complements the growing multitude of special-purpose whistleblowing laws.

Here the High Court's decision in WorkChoices (2006) ${ }^{66}$ becomes an important consideration in the future recognition and enforcement of these employer obligations. Previously, the quest for recognition of employers' obligations to protect whistleblowers would have relied on statutory reform in every state and federal jurisdiction. After WorkChoices, the terms and conditions of employment in all Australian trading or financial corporations are to be regulated exclusively by the federal workplace relations system. While employers who are not corporations - in particular, state government departments - may continue to be regulated by state industrial tribunals in many instances, the shift makes it clear that if general recognition of employers' obligations towards whistleblowers is to be strengthened, then certainly in respect of private sector employers the starting point is amendment of the

63 Public Company Accounting Reform and Investor Protection Act of 2002, Pub L No. 107-204, 116 Stat 745, 18 USC ('Sarbanes-Oxley Act of 2002'). Section 806 (Protection for employees of publicly traded companies who provide evidence of fraud) added s 1514A (Civil action to protect against retaliation in fraud cases) to USC Ch 73 Title 18, which provides for whistleblower protection for employees of publicly traded companies. See Baynes (2002).

${ }^{64}$ See, for example, Latimer $(2002,2003,2004)$.

${ }_{65}$ See Brown (2006), pp 14-15 for an argument that this multiplicity is here to stay, and that therefore private sector issues would be better removed from the current South Australian and Queensland laws.

66 New South Wales \& Ors v Commonwealth of Australia [2006] HCA 52; (2006) 81 ALJR 34. 
Workplace Relations Act 1996 (Cth). Careful drafting is needed to ensure that the lessons of existing state and territory public sector legislation are fully learned in the framing of those circumstances in which legal protection of whistleblowers should arise. ${ }^{67}$ Extension of state and territory workplace relations laws is also needed to ensure that efficient compensation mechanisms are created, in parallel with those now more simply achievable at a federal level. However, the WorkChoices case now clearly delivers the prospect of a simpler reform path than would otherwise have been necessary, in which whistleblower protection obligations such as described in the previous part can be fairly easily extended to all major private sector employers, federal government agencies, those state and territory governments that opt in to the federal workplace relations system, and all employers who come under the purview of the federal system by virtue of actual or potential disputes extending beyond the boundaries of any one state or territory.

\section{Conclusions: Symbols or Substance?}

This article has reviewed five key issues for consideration in the reform of current Australian public interest disclosure laws. These issues confirm the strong case for greater consistency in the key legal thresholds and operational requirements imposed by Australian whistleblower protection regimes, and the need for care to be taken in considering how reform can best be pursued in a manner that recognises the complexity of existing laws, but also emphasises and strengthens employers' obligations to protect public-interest whistleblowers irrespective of whether they are found in the public or private sectors. In large part, the prospect for accelerating the transition towards more effective, less 'symbolic' regimes depends on a clearer consensus regarding the public importance of employee disclosures and the organisational advantages of open, proactive approaches to disclosure management.

The extent of the inconsistencies and gaps in existing laws comes as stark confirmation that there is indeed a divide between their important intentions or 'symbolism' and their substantive effectiveness. The symbolism of whistleblower protection is a powerful force, continually reaffirmed in political rhetoric, but as this analysis shows, the reality is that most existing laws have only directly tackled parts of the necessary legal obligations. In particular, existing legislation has been comprehensive in removing legal impediments to whistleblowing, but these were never the major legal problem, and even so, current laws continue to fail to deal with those circumstances of public whistleblowing to which these reforms were meant to apply. As a result, there is strength to the argument that current whistleblower protection laws - while symbolically very important in promoting the legitimacy of public interest

67 For example, under the Corporations Act 2001 (Cth), s 1317AA(e) and Workplace Relations Act 1996 (Cth), Sch 1B, Ch 11, s 337A(e) a disclosure will only be protected where made 'in good faith', whereas most public sector legislation sensibly avoids such a problematic threshold by simply requiring either that the disclosure tends to show wrongdoing, or is accompanied by an honest and reasonable belief that it does, irrespective of motives and issues such as malice: see Brown (2006), pp 24-25; cf House of Representatives (2004), p 5.391. 
disclosures - have so far added relatively little to the practical realities of whistleblower protection itself. The substance of most of the current laws is so basic that one can legitimately wonder why they were needed at all, given that pre-existing laws often already provided a legal framework in which the role of whistleblowers could or should have been recognised.

Governments' universal conclusion that separate, stand-alone legislation was needed — with or without associated amendments to other legislation therefore itself confirms the very great challenges and practical difficulties that accompany the realities, as opposed to the mere legal possibility, of facilitating disclosures by protecting those who make them. For disclosures to come to light, and for those who make them not to suffer unnecessarily, organisational cultures need to transform from closed hierarchies in which risks of mistakes or wrongdoing are not openly acknowledged, to more reflexive environments with much more sophisticated systems for ensuring that individuals and organisations take responsibility for problems and deal more constructively and efficiently with conflicts. Currently, the symbolism of whistleblower protection is very clearly endorsed by an increasing amount of legislation, as well as by new statistical evidence of the attitudes of public employees. Most recently, it has been endorsed by the new Commonwealth government's commitment to introduce entirely new, comprehensive, 'best practice' public interest disclosure legislation. Whether this can translate into the necessary protection of whistleblowers in substance, is dependent on whether the proposed reforms can line up with those symbolic principles in a manner that is more effective than achieved by much of the legislation to date. Solving these problems, then, becomes a significant test of a substantive as opposed to merely symbolic commitment to public integrity and open government.

\section{References}

\section{Secondary Sources}

Leonard Baynes (2002), 'Just Pucker and Blow? An Analysis of Corporate Whistleblowers, the Duty of Care, the Duty of Loyalty, and the Sarbanes-Oxley Act', 76 St. John's Law Review 875.

AJ Brown (2006) Public Interest Disclosure Legislation in Australia: Towards the Next Generation - An Issues Paper, Commonwealth Ombudsman, NSW Ombudsman, Queensland Ombudsman.

AJ Brown (2007), 'Privacy and the Public Interest Disclosure: When is It Reasonable to Protect "Whistleblowing" to the Media?' 4 Privacy Law Bulletin 2.

AJ Brown (ed) (2008), Whistleblowing in the Australian Public Sector, Australia and New Zealand School of Government Research Series/ANU E-Press, forthcoming.

AJ Brown, Douglas Magendanz and Coral Leary (2004), Speaking Up: Creating Positive Reporting Climates in the Queensland Public Sector, Queensland Crime \& Misconduct Commission (Building Capacity Series).

Jonathan Carson (2006), 'The Need for Whistleblowing Legislation in Canada: A Critical Defence', paper presented to the Canadian Political Science Association Conference, www.cpsaacsp.ca/papers-2006/Carson.pdf. 
Hon Geoffrey Davies (2005), Report of Queensland Public Hospitals Commission of Inquiry, Queensland Government.

Guy Dehn (2006), 'Taking Whistleblower Protection Seriously', presentation to $6^{\text {th }}$ National Investigation Symposium, Sydney, 4 November, Institute of Public Administration Australia (NSW), Independent Commission Against Corruption \& NSW Ombudsman.

William De Maria (1999), Deadly Disclosures: Whistleblowing and the Ethical Meltdown of Australia, Wakefield Press.

Helen Ester (2006), 'Corruption and the Media: Political Journalists, "Leaks" and Freedom of Information', in Proceedings of the $2^{\text {nd }}$ National Conference of Parliamentary Oversight Committees of Anti-Corruption/Crime Bodies, NSW Parliament House.

House of Representatives (2004), Corporate Law Economic Reform Program (Audit Reform and Corporate Disclosure) Act 2004: Explanatory Memorandum.

Damian Grace and Steven Cohen (1998) 'Whistleblowing', in Business Ethics: Australian Problems and Cases, Oxford University Press.

Jane Baker Jones (1996), 'Whistleblowing — No Longer Out of Tune' 66 Australian Accountant 7.

Paul Latimer (2002), 'Reporting Suspicions of Money Laundering and "Whistleblowing”: The Legal and Other Implications for Intermediaries and Their Advisers' 10 Journal of Financial Crime 23.

Paul Latimer (2002), 'Whistleblowing in the Financial Services Sector' 21 University of Tasmania Law Review 39.

Paul Latimer (2003) 'Whistleblowing in the Insurance Industry' 77 Australian Law Journal 614.

Paul Latimer (2004), 'Whistleblowing in the Financial Services Sector (Part 2)' 23 University of Tasmania Law Review 176.

Eva Lomnicka (1990) 'The Employee Whistleblower and His Duty of Confidentiality' 106 Law Quarterly Review 250.

Andrew Murray (2003), 'Whistleblowers and Their Role in Civil Society and Need Federal Protection', posted on On-Line Opinion - Australia's e-Journal of Social and Political Debate, 23 October 2003, www.onlineopinion.com.au/view.asp?article $=810$.

Janet Near and Marcia Miceli (1985) 'Organisational Dissidence: The Case of Whistleblowing' 4 Journal of Business Ethics 1.

NSW Ombudsman (2004) The Adequacy of the Protected Disclosures Act [NSW] to Achieve Its Objectives, Issues Paper, April 2004/June 2005.

NSW Ombudsman (2005) Public Sector Agencies Factsheet No 23, Whistleblowing, www.ombo.nsw.gov.au/publications.

NSW Ombudsman (2006) Good Conduct and Administrative Practice - Guidelines for State and Local Government, 2nd ed.

Laurie Oakes (2005) 'Pillars of Democracy Depend on Leaks', The Bulletin/National Nine News, 24 August, http://news.ninemsn.com.au.

Peter Roberts (2008) 'Whistleblowing Legislation and Procedures: How Do Agencies Currently Manage Whistleblowing?' in AJ Brown (2008), Whistleblowing in the Australian Public Sector (Australia and New Zealand School of Government Research Series), ANU E-Press, forthcoming. Royal Commission into NSW Police Service (1997), Final Report, Volume II.

Kevin Rudd MP and Senator Joe Ludwig (2007), Government Information: Restoring Trust and Integrity (Election 2007 Policy Document), Australian Labor Party.

Senate Select Committee on Public Interest Whistleblowing (1994) In the Public Interest (Parliamentary Paper No. 148/1994, August 1994).

Hedley Thomas (2007), Sick to Death, Allen \& Unwin. 
John Walter and N Erlich (1989), 'Confidences - Bankers and Customers: Powers of Banks to Maintain Secrecy and Confidentiality' 63 Australian Law Journal 404.

\section{Cases}

Alberta Union of Provincial Employees v Alberta 2000 ABQB 600.

Bennett v President, Human Rights and Equal Opportunity Commission [2003] FCA 1433.

Fraser v Public Service Staff Relations Board [1985] 2 SCR 455.

Iacob Guja v Moldova [2008] European Court of Human Rights, Application No. 14277/04, 12 February 2008.

Lange v Australian Broadcasting Corporation (1997) 189 CLR 250.

New South Wales \& Ors v Commonwealth of Australia [2006] HCA 52, (2006) 81 ALJR 34.

Re a Company's Application [1989] 3 WLR 265.

Tournier v National Provincial and Union Bank of England [1924] 1 KB 461.

Wheadon v State of NSW, District Court of NSW, No 7322 of 1988 (2 February 2001).

\section{Legislation}

Corporations Act 2001 (Cth).

Corporate Law Economic Reform Program (Audit Reform and Corporate Disclosure) Act 2004 (Cth).

Crime and Misconduct Act 2001 (Qld).

Employment Rights Act 1996 (UK).

Independent Commission Against Corruption Act 1988 (NSW).

Industrial Relations Act 1999 (Qld).

Public Company Accounting Reform and Investor Protection Act of 2002, Pub L No. 107-204,

116 Stat 745, 18 USC (Sarbanes-Oxley Act of 2002).

Protected Disclosures Act 1994 (NSW).

Public Interest Disclosure Act 1994 (ACT).

Public Interest Disclosures Act 2002 (Tas)

Public Interest Disclosure Act 2003 (WA). Public Interest Disclosure Bill 2001 (Cth).

Public Interest Disclosure Bill 2006 (ACT).

Public Interest Disclosure Bill 2006 (NT).

Public Interest Disclosure Bill 2007 (Cth).

Public Interest Disclosure (Protection of Whistleblowers) Bill 2002 (Cth).

Public Service Act 1999 (Cth).

Whistleblowers (Disclosure to Member of Parliament) Amendment Act 2007 (Qld).

Whistleblowers Protection Act 1993 (SA).

Whistleblowers Protection Act 1994 (Q1d).

Whistleblowers Protection Act 2001 (Vic).

Whistleblowers Protection Regulations 2001 (Vic).

Workplace Relations Amendment (Codifying Contempt Offences) Act 2004 (Cth).

Workplace Relations Act 1996 (Cth).

Whistleblowers Bill 2006 (NT). 